\title{
Forging a Union? Some Reflections on the Early Jagiellonian Monarchy
}

\author{
Stephen C. ROWELL
}

The dual monarchy of the Grand Duchy of Lithuania and the Kingdom of Poland, plans for which were confirmed by Jogaila in his castle at Kreva in August 1385, acknowledged and finally timetabled on the Polish side mainly by the Malopolskan nobility under the leadership of Władysław of Opole on January 11, 1386 (at Volkovysk), blessed by Queen Elisabeth of Hungary and put into effect by the Grand Duke's baptism and marriage to Queen Jadwiga in Kraków in February $1386^{1}$, dominates not only the four centuries of the Lithuano-Polish joint state, but also heavily overshadows the history and psyche of the Union's successor polities, the twentieth-century Republics of Poland and Lithuania. Real politicians of the stature of Jogaila and Vytautas have been largely erased from history to be replaced by superheroic national ciphers, and the Gediminid line almost overlooked so that historians could interpret the dynastic relationship between the two cousins as the subordination of one state, Lithuania, to another, Poland. The Lithuanian reaction has been to caricature Jogaila as "Polish" and deify Vytautas ${ }^{2}$. The present sketch examines briefly the so-called Union of Krèva and its implementation in a broader context, hoping to help de-mythologise images of LithuanoPolish statehood and highlight areas where further research is needed.

Setting aside the external pressures which faced the Grand Duchy from the north and west (the Teutonic Ordensstaat in Prussia and Polono-Hungarian ambitions in Red Rus') and the Polish Kingdom from the south and east (the civil war in Hungary and the Lithuanian presence in Volyn' - relations with the Order, although not

${ }^{1}$ Akta Unji Polski z Litwa 1385-1791 [AUPL], oprac. S. Kutrzeba, W. Semkowicz, 1, 2, Kraków, 1932, 1-4; Skarbiec Dyplomatów, oprac. I. Daniłowicz, I, Vilnius, 1860, 518, 260; Dhugosz, Annales seu cronicae incliti regni Poloniae, X, oprac. D. Turkowska, Warsaw, 1985, 153-157. The Union has been subject to so much study that it is impossible to give adequate bibliographical guidance here. The reader would do well to peruse: J. Bardach, Lunion de Lublin: ses origines et son role historique, Acta Poloniae Historica, XXI, 1970, 69-92; J. Kiaupienè, Historia litewska o niektorych zagadnieniach stosunków litewskopolskich między Krewem a Lublinem, in Profesor Henryk Łowmiański, zycie i dzieto, oprac. A. Kijas, K. Pietkiewicz Poznan, 1995, 116-123; Z. Kowalska-Urbankowa, Unia Polski i Litwy w latach 1385-1413 w najnowszej historiografii polskiej, Analecta Cracoviensia XIX (1987), 207-221.

2 D. Kuolys, Asmuo, tauta, valstybe Lietuvos Didžiosios Kunigaikštystès istorinèje literatūroje. Renesansas, barokas,Vilnius,1992. 
good, were also not belligerent), we may assert that the Lithuano-Polish union was conceived and brought to effect under intense domestic conditions, dynamised by the conflicting and interdependent interests of three groups: (1) the privileged nobility of the kingdom of Poland, especially the lords of Malopolska, bereft since 1370 of a native ruling house to serve and exploit. This southern duchy had strong interests in establishing peace in regions to the south and east of the Kingdom, whilst trying to diminish the influence gained by Wielkopolskan nobles during the reign of Louis of Anjou. (2) Political forces within the Grand Duchy of Lithuania outside the main line of the House of Gediminas, namely princes not of Jogaila's direct line - such as his cousins, brothers and half-brothers who had established themselves in Lithuania's Russian duchies - and a growing number of powerful dukes, soon to be joined after the Union by a privileged and increasingly self-conscious boyarate. (3) The close family of Jogaila Algirdaitis. The dual monarchy came into being because all three parties could benefit from it, or in the second case, could not prevent it in the first instant. A Cracow prelate, Jan of Kluczbork, in an address delivered after the victory at Grunwald in 1410 under the rubric "pro honore regis Polonie", succinctly identified the defence of the realm as secured by the majesty of the king, the might of his cousin Vytautas, the grand duke, the fellowship of Queen Anne's friends and the fidelity of many other worthy persons ${ }^{3}$.

Whilst the internal difficulties of the Grand Duchy of Lithuania are reasonably familiar to historians, especially against the pan-union backdrop, there remains a tendency not to view the disputes which characterise the life of the late fourteenth- and early fifteenth-century Poland in the context of the Union. Various local ducal interests competed with one another, with the Little Polish nobility led by Cardinal Oleśnicki taking the upper hand, where close links with Lithuania are concerned. The dominant question was who controlled the Kingdom: the aristocracy or the "elected" king (usually also recognised as heir to the crown). The nobles came to style themselves tutores regni - a title borne in 1386 by Jogaila before his coronation as King ${ }^{4}$. Jogaila and his sons wished to incorporate the Kingdom into their patrimony alongside the Grand Duchy. In the Grand Duchy itself Jogaila was compelled to concede effective government to his cousin Vytautas, who in his turn found it necessary to grant political privileges to a growing number of boyars and even to enter into marriage alliances with one local family: the Alšèniškiai (Holszanscy). These boyars began to form their own groupings which conflicted with the Grand Duke and King. During the minority of Grand Duke Casimir (1440-47) the small group of families which was to dominate

${ }^{3} \mathrm{Z}$. Budkowa, Mówa mistrza Jana z Kluczborka na cześć króla Władysława Jagiełły, in Mediaevalia w 50-ta rocznice pracy naukowej Jana Dabrowskiego, Warsaw, 1960, 175.

${ }^{4}$ AUPL, 6, 1932, 6: Michal of Zaslaw's act of homage, March 1, 1386; "dominus et gubernator": Kodeks dyplomatyczny Matopolski IV, 969 (March 3, 1386). 
Lithuanian society in the fifteenth and early sixteenth century was already gelling as a powerful political elite. The union is the most ambitious example of traditional Lithuanian dynastic policy in face of pressure for power within the Grand Duchy: domestic political inconveniences should be avoided by seeking land beyond the borders of the Lithuanian patrimony. While such methods succeeded for Mindaugas and Gediminas, in the fifteenth century they led to the overstretching of the state apparatus, viz. the dynasty, which could not consolidate its position in Hungary and Bohemia, whilst the deliberate absence of junior Jogailaičiai from the Grand Duchy strengthened the head of the local aristocracy.

Since the mid-fifteenth century union scholarship has tended to serve contemporary factional political needs, aided by the dearth of direct sources for the union's early history. One text, confirming the authenticity of Jogaila's proposals as received by the dowager queen of Hungary-Poland, survives from August 1385 (the Act of Krèva). The Polish preparations for the final embodiment of the union are recorded in a text sent to Jogaila from Volkovysk in January 1386 on behalf of the Kingdom's nobility, headed by Duke Władysław of Opole, a Wielkopolskan magnate supporter of the Angevin line and "prince" of Polish Red Russias. A declaration of maternal love on the part of Queen Elisabeth towards Jogaila was made in Buda some time in 1386, presumably before or shortly after the prince's conversion. No treaty of union, however, survives. All subsequent surviving texts were written by spokesmen of particular parties: Dhugosz followed the Malopolskan noble line that the Jagiellonians were elective rulers, for their power dependent on aristocratic approval, omitting all reference to dynastic contracts from his account of 1385 . This line was taken immediately after Jogaila's death when Bishop Nicholas Lasocki of Poznan reported on Lithuano-Polish affairs to the Council of Basel, that Jogaila had been elected by the nobility and that Lithuania had been administrated by Vytautas, who understood himself to be governor on behalf of the Polish Crown ${ }^{6}$. Jogaila's own political agenda is not served

${ }^{5}$ This text is also decried as a forgery. The text makes no reference to Jogaila as "Władysław", but to the duke of Opole, as Dainauskas alleges. For the complex mechanism of embassies surrounding mediaeval treaty making in general, see: G.P. Cuttino, English medieval diplomacy, Bloomington,1985, 1-24; for another central European example, cf. election of Władysław Jogailaitis as king of Hungary in 1439-40: J. Długosz, Historiae polonicae libri XII, oprac. A. Przedziecki, IV, Kraków,1878, 615-619; and J. Dąbrowski, Władysław I. Jagiellończyk na Węgrzech (1440-1444), Rozprawy historyczne Towarzystwa naukowego Warszawskiego, II,1, Warszawa, 1923.

6 "dux satis diu resistebat, questiebat se terrarum illarum non esse dominum sed gubernatorem et terrebat offendere regem": Schloss Zeil, Ms 28, f.244. "Magna mendacia" was published in part in K. Forstreuter, Eine polnische Denkschrift auf dem Konzil in Basel, Z. Ostforschung, XXI, 1972, 684-696; full edition of this sermon, read in Basel on November 5, 1435 is published with translation and commentary in Acta Historica Universitatis Klaipedensis, 1996. On the political bias of fifteenth-century historical collections, see: J. Wiesiołowski, Kolekcje historyczne w Polsce średniowiecznej XIV-XV wieku, Wrocław-Warszawa-Kraków, 1967, 148-163. 
richly by written treatises and it goes without saying that Jogaila could not defend his dynasty's rights posthumously, when both his heirs were minors on whose behalf noble regents governed. A good example of surviving Jagiellonian propaganda is the sermon preached by Jan of Ludzisko before the University of Cracow in June 1447 which stresses Casimir Jogailaitis's accession to his two patriae. In the absence of Jogaila's last will and testament, we might consider the careful appointment of two guardians, one each from Lithuania and Poland, for his heir in 1425 as evidence of the distinct nature of the two realms Jogaila would leave to his sons ${ }^{8}$. From the late-fifteenth century Lithuanian nobles also came to promote themselves as traditional co-rulers in the Grand Duchy with the House of Jogaila.

In the nineteenth century the increasingly separate struggles on the part of Lithuanians and Poles to restore the independence of the Two Nations from the Partitioning Powers provoked an additional academic complication, namely, what do written sources, especially tendentious or jejune ones, mean to scholars who lack practical political experience? A treaty which speaks of perpetual union is not necessarily valid forever. Words and deeds are not always the same, and forever, perpetuo, is a short time in politics. The debate over the union has been dominated by sterile arguments over significance of the word applicare (join, bring or glue together) in the Kreva document, or the later addition incorporare, and whether these can be used to subordinate Lithuania to Poland in the past, today and forever. Such an unhistorical analysis led one commentator even to doubt the authenticity of the document which records preliminary ratification of the union negotiations 9 . Only in the 1970 s did Polish and Lithuanian scholars soberly define the agreement for what it is, a marriage contract between two princes and explore its rather surprisingly limited implementation ${ }^{10}$. The emphasis which has been laid by Lithuanian historians on the theme of "savarankiškumas", understood as political separation from the kingdom of Poland tends to mislead. One is able equally well to speak of Polish political particularism(s) - or attempts of certain social groups to distance themselves from or control the crown. What then are the events under review?

7 “...] in quo eximium illud decus adest, quod ex patricia et ducum Lythwanorum familia effulsit, que tot seculis ornatissimas ymagines consulares, pretorias, triumphales ducta, in hunc diem potens illustrisque perdurat. Terram enim Lythwanie clarissimam utique patriam dicerem... Accedit ipsa Polonorum patria. Singularis illius laus est", in Codex epistolaris saeculi XV, oprac. A. Lewicki, III, 8, Kraków, 1894.

${ }^{8}$ See below, n. 031.

9 J. Dainauskas, Kriavo akto autentiškumas, in Lituanistikos Instituto 1975 mety suvažiavimo Darbai, Chicago,1976; Lietuvos bei lietuviu krikštas ir 1387-ji metai, Chicago,1991, $49 \mathrm{f}$.

${ }^{10} \mathrm{E}$. Gudavičius, Krèvos sutarties $(1385 \mathrm{~m}$.) tikslai ir jų igyvendinimo galimybès, $L M A D A, 1(58), 1977,67-74$; J. Bardach, Krewo i Lublin. Z problemów unji polskolitewskiej, in Studia $z$ ustroju i prawa Wielkiego Księstwa Litewskiego XIV-XVII w., Warsaw,1970, 11-67. Having demonstrated admirably the patrimonial aspects of the 1385/6 union, Professor Bardach then went on to retract a little from his conclusions and write of incorporation - ibid., 65. 
On August 14, 1385 Grand Duke Jogaila of Lithuania ratified the conditions of an agreement discussed by his envoys and representatives of Queen Elisabeth of Hungary and the nobility of Malopolska. According to this agreement, which survives only in this ratification text and later edited chronicle accounts, Jogaila consented to adhere his ancestral realm to his new inheritance, the Kingdom of Poland. The agreement was to be sealed by the marriage of the newly converted grand duke-king to the queen of Poland, Jadwiga. The latter's mother was requested to adopt Jadwiga's husband as her son. According to the terms of the treaty, Jogaila promised to pay compensation on behalf of the Queen of Hungary to the Austrian father of his bride's jilted fiancé, to make good all Poland's losses by his own labours and at his own expense; to free Polish prisoners of war held captive in Lithuania; to baptise as Catholics all the pagans in his realm and to join those lands of Lithuania and Russia with the Polish Crown forever: promittit terras suas Lituanie et Rusie corone regni Polonie perpetuo applicare ${ }^{11}$. The accounts of the agreement as given by Długosz sub anno 1385 and again as part of a speech by Olesnicki in 1448 do not exactly reflect the text we have from Kreva. The Polish chronicler omits all mention of Jogaila's being adopted by Elisabeth and mentions a promise to bring all the Lithuanian treasury to Poland - as opposed to the promise to repair war damage incurred in the Kingdom out of the Lithuanian purse ${ }^{12}$.

Elisabeth reacted to Jogaila's proposal of adoption and marriage positively and as required, maternally. It may be worth bearing in mind that it was the queen's confessor, Andrzej Jastrzębiec, who became the first Catholic bishop of Vilnius. The queen was murdered in Bosnia in 1387, ending any future influence she may have had on the dual monarchy, and the Magyar royal archive was destroyed by the Ottomans during the 1525 sack of Budapest: the lack of surviving documentary evidence is, therefore, no surprise. Legal historians have paid too much attention to the phrase perpetuo applicare (which can imply almost whatever the reader wishes it to imply, from long term friendship to eternal marriage) and too little to the first clause which establishes Jogaila's adoption, marriage and implied rights of inheritance. This patrimonial concept of politics formed the basis of the British, Spanish and Habsburg imperial monarchies. It was the mark too of the short-lived Anglo-French dual monarchy of Henry VI. S. Russocki may be correct to assert that in the fifteenth century more

${ }^{11}$ AUPL, 1, 1932, 2. How exactly this document should be categorised is discussed in an article by J. Kiaupiené, " $1385 \mathrm{~m}$. aktas Lietuvos ir Lenkijos unijos istorijoje ir istoriografijoje (problemos formulavimas), in Lietuvos valstybe XIII-XVIII a., Vilnius, forthcoming. The debate is perhaps pedantic in the extreme, but it remains important whilst politically motivated patriots fail to see that certain faults lie in the student and not the studied.

12 Dhugosz, X, 142-143; XII, 47; in general on Dhugosz's account of 1385, see: S.M. Kuczynski, Rozbiór krytyczny roku 1385 “Dziejów polskich" Jana Długosza, Studia Zródtoznawcze, III, 1958. 
love and loyalty was paid to the Crown as an idea than to the king as a person in certain realms ${ }^{13}$. However, this was not the only view, nor was it, perhaps, the most fashionable one. It smacks more of aristocratic political circles where the nobles attempted to assume guardianship of the crown. That the Lithuano-Polish state did not develop a successful centrally-propagated political identity is a fact, but that certain other realms did was not an inevitability.

The negotiation stance ratified at Krèva focusses on two heiresses, Elisabeth and Jadwiga, and Jogaila's desire to enjoy hereditary rights as regards the Polish crown. Jogaila wished to be recognised not only as Queen Jadwiga's husband, but also as the son of Queen Elisabeth, widow of the last king of Poland, Louis of Hungary and niece of the restorer of the Piast kingdom, Władysław Lokietek. It was no accident that the grand duke baptised himself Władysław, a name passed on to his first born son. His second heir, Casimir, was named for Lokietek's son, the last and "great" Piast king of Poland. Jogaila understood power as a possession inheritable through both adoption and marriage ${ }^{14}$. It is clear that this Lithuanian dynasticism encountered increasing opposition from aristocratic circles in both the kingdom and the grand duchy, especially during the reign of Casimir Jogailaitis ${ }^{15}$.

The group of Russian sources, including the Novgorodian Fourth Chronicle and a late fifteenth-century Muscovite compilation, which mentions the conversion of Lithuania to Latin Christianity, also emphasises that Jogaila went to Hungary to marry the queen and was baptised there. An interesting slant on the chronicle record is provided by the Suprasl' annals, which combine a general Russian account with data from the Grand Duchy: the eastern half stresses the Hungarian connection, whilst the later Lithuanian entries mention the role of the Polish nobility and the death of Casimir the Great which foreshadowed the union:

After his marriage but before his coronation Jogaila was styled protector of the realm (tutor regni Polonie ${ }^{16}$ ). Through Jadwiga and with Jadwiga, Jogaila was king of Poland in his own right. After March 1386 his position in Poland was not dependent solely on his wife, as certain mediaeval and modern Polish propagandists claim. Even regina vivente Jogaila disposed of Polish lands as king and heir, as is illustrated by the case of Siemowit of Mazovia who was endowed

${ }^{13}$ S. Russocki, Medieval political nations in central Europe, Quaestiones Medii Aevi, IV, $1990,74$.

14 "Nie był już panem naturalnym i dziedzicem królestwa, ale męzem jego dziedziczki, a koronę otrzymał z rąk jego mieszkańców", in J. Krzyzaniakowa, Regnum Poloniae w XIV wieku. Perspektywy badań, in Sztuka i ideologia XIV wieku, oprac. P. Skubiszewski, Warsaw, 1975,78 . This view is negated even by the titles of Jogaila and his wife, which were identical.

${ }^{15}{ }^{15}$ See S.C. Rowell, Bajorų maištai Lietuvos Didžiojoje Kunigaikštystėje 1440-1481 m. - (forthcoming).

${ }^{16}$ See above n. 3. 
with Belz by the king "iure hereditario et eo iure et dominio quo ipsa soli tenuimus et possedimus"17. Jogaila was a consummate and extremely lucky gambler. He granted part of Lithuania to his wife as her morning gift. In 1398 the pregnant queen required the payment of dues from her Lithuanian lands at exactly the time she was expecting her (and Jogaila's) heir ${ }^{18}$, but both she and the child predeceased him. Throughout his long reign, Jogaila gambled his crown against the ambitions of his kinsmen, Vytautas, Švitrigaila and Žygimantas Kęstutaitis. The agreements he made concerning the Grand Duchy were founded on the hope that he would outlive his competitors who potentially might otherwise come to control Poland, should he die without an heir of his body. After his election as king of Poland in 1447 , Casimir sedulously strove to prevent his kinsmen from regaining power in the Grand Duchy. He steadfastly refused to appoint a lieutenant for the Grand Duchy even from among his sons ${ }^{19}$. The outcome of this thirteenth-century policy in the fifteenth century was to overspread the dynasty further in geographical terms (with Casimir's sons in Bohemia and Hungary rather than Lithuania) and left a political presence vacuum in the Grand Duchy to be exploited by the nobility. An attempt to solve the problem of the monarch's need to be simultaneously in two places was made by progressing around the two realms. Jogaila's itineraries reveal neatly how he concentrated his progresses in Poland during the opening decade of his reign, especially in Malopolska, clearly in an effort to imprint his authority, whereas later he divided his time more fairly between the Kingdom and the Grand Duchy. Casimir IV did likewise. The growing aristocratic circles in both realms were greedy for royal appointments and a share of court life and monarchical transmigration was not exactly what the baronages wanted.

Soon after his marriage and coronation Jogaila forged affinities with the remaining Piast ducal lines in Silesia (where his sister Jadwiga was married off to Duke Jan II of Oswięcim in 1394, eight years after their brother Wigand Aleksander married Jadwiga of Opole (1386), daughter of Siemowit III of Mazovia), Pomorze (in 1388 Wilhejda Algirdaité wed Jan II of Mecklemburg) and Mazovia. Until this time Lithuano-Piast marriages, especially in Mazovia, had involved the close family of Vytautas rather than that of Jogaila. Now the Algirdaitis needed to foster Piast support ${ }^{20}$. The nobleman, Spytko of

${ }^{17}$ Iura Masoviae terrestria I, oprac. J. Sawicki, Warszawa, 1972, No. 45, 67; see also: A. Swiezawski, Nadanie ziemi bełskiej Siemowitowi IV, in Przeglad Historyczny, LXXII 1981, 269-286.

18 "dy lant czu Russin und Littowen bescheydin hette in der morgingabe und gegebin uff dy cziit, als sy yn genomen hette czu eyme herren": Johann v. Posilge, Chronik, in Sriptores renum prussicanum [SRP], III, 219

19 "der herre grosfurste von Littauwen koning ist gewurden und gekronet zcu Polan und behelt beide landt, als wol Littauwen als Polen, und ist sust kein grosfurste zcu Littauwen", in Liv-, Est- und Kurländisches Urkundenbuch nebst Regesten, gearb. F.G. von Bunge, X, 378, Riga-Moscow, 1896; Aalen, 1981, 258; Długosz, XIII, 669-670, 698.

${ }^{20}$ See: G. Błaszczyk, Małzeństwa dynastyczne polsko-litewskie od XIII do XV wieku, in Profesor Henryk Łowmiański, zycie i dzieło, 98-115; S.C. Rowell, Pious princesses or the daughters of Belial? Pagan Lithuanian dynastic diplomacy, 1279-1423, Medieval Prosopography XV, 1 1994, 3-80. 
Melsztyn accepted land from Jogaila in $1395 / 6$, much to the annoyance of Jadwiga and her noble entourage; it seems that they had not expected the pagan grand duke to make such inroads into the political elite of Poland. Spytko, like Siemowit of Mazovia, was being treated like a normal Lithuanian princeling. Perhaps it is legitimate to suggest also that his treatment reflects that of a pretty normal, if a little oldfashioned, Polish duke. For Dlugosz, writing more than fifty years after the event, however, it was clear that Jogaila granted these territories to Spytko "iure suo regali" 1 .

When Jadwiga died in August 1399, Jogaila was the sole suzerain of both the kingdom of Poland and the Grand Duchy of Lithuania. Since 1392 Jogaila had recognised Vytautas's rule in Lithuania, granting him the title of grand duke, whilst reserving for himself the higher style of "supreme duke". This tradition of political pragmatism continued during periods where real and titular power were divorced from one another, as when Władysław III was in Hungary but styled himself "supreme" and his brother Casimir ruled as grand duke in Lithuania. A similar position came to pass at the level of lieutenant in Žemaitija following the rebellion of 1440-41, after which Kontautas, the leader enjoying most local support, retained his office as houptmann and Kęsgaila, the Vilnius appointee, was oberhauptmann ${ }^{22}$.

Jadwiga provides in death a telling commentary on the realities of Jogaila's position in the union. She was buried in an unobtrusive part of the royal cathedral in the Wawel, where a marble effigy was erected for her as late as 1902 . This contrasts sharply with the fate of Jogaila and his other queens who were provided with impressive funerary monuments. Some commentators have interpreted this as the effect of Jadwiga's pious humility and her handsome testamentary bequests which left no funds for such "immodest" marmoreal extravagance. Another theory argues that the cult of the queen was expected to finance a suitable tomb before too long and hence a delay arose which, like Topsy, growed and growed ${ }^{23}$. There may be, of course, another explanation. Jadwiga's political importance for the ruling house ended, for the most part, with her death. She was no longer necessary to Jogaila who needed to furnish himself with a male heir. Her cult appears to have begun on a larger scale only in the mid-fifteenth century when Malopolskan ideologists such as Dhugosz began to write about and reconstruct her life. Her great popularity dates from the

21 "pleno iure ducali, quo ceteri nostri duces Lithuanie et Russie frui soliti sunt", in Codex epistolaris Vitoldi magni ducis Lithuaniae, oprac. A. Prochaska, 115 (139.VI. 13), Kraków,1882; New York, 1965, , 38; Długosz, X, 217 s.a. 1396. and XIII [Historiae polonicae libri $X I I$ ], 48, s.a. 1448.

22 Władysław III's style: "Wladislaus Dei gracia Hungarie, Polonie, Dalmacie, Croacie etc Rex, Lithwanieque princeps supremus et heres Russie" (02.06.41), in Knigi pol'skoi koronnoi metriki XV stoletia,I, 10,1447-1454, Warsaw, 1914, No.10, p.9. For the style of the Žemaitijan lieutenants, see: Rowell, Bajorų maištai...

${ }^{23}$ K. Szymonowicz, Droga królewska na Wawel, Warszawa-Kraków, 1987, 112-113. 
nineteenth century. It was important to the Polish noble parties that Jadwiga rather than Jogaila be regarded as sole and true heir to the Polish throne and that after her death Jagiellonian power should depend on the approval of the nobility rather than the laws of inheritance. It is therefore no surprise that in his account of the pre-nuptial agreement arranged between Jogaila and Queen Elisabeth, Długosz mentions all the points featured in the Kreva document except the adoption of the grand duke by Jadwiga's mother. Dhugosz mentions that the king feared that he had no right to remain in Poland after Jadwiga's death - a fear which appears to be part of Oleśnicki-Długosz political doctrine. Jogaila's choice of the second wife can also be linked with his desire to strengthen his own contacts with the Piast line, as the Grand Master indicated in his letter to the Commander of Vienna in October 139924. Anne of Cilly was Casimir III's great-greatgranddaughter and hence through Casimir's wife Aldona-Anna, a descendant of Gediminas. However, it is clear from acts of homage made to Jogaila and his children later that the hereditary principle was still viable in the dynasty's constitutional position.

Rather than fearing for his future in Poland, Jogaila set out to strengthen his position in the union as a whole. In January 1401 he demanded a new treaty with Vytautas before embarking on his next marriage. Although Vytautas's political ambitions were somewhat curtailed by his defeat in battle with the Tatars at Vorksla in 1399, the Treaty of Radom-Vilnius seems to have been provoked as much by the need to clarify matters after Jadwiga's death, as by temporary Lithuanian military weakness. Jogaila recognised Vytautas as grand duke but only for life. At his death Vytautas was to return the Grand Duchy to Jogaila along with the greater part of his own paternal inheritance, thereby consolidating the ruler's holdings in the Grand Duchy. Were patrimonial matters within the dynasty and the Grand Duchy not paramount here, should be forced to conclude that the lands which were not escheat to Jogaila also not to be part of the Grand Duchy? There is no need to talk of Lithuania's gaining recognition as being an equal partner in the Union ${ }^{25}$; she was never less than equal before the law, even if in the trappings of church and Christian state, she was somewhat less developed. The gamble on Jogaila's part was that in return for Vytautas's oath of allegiance to him, his heirs and his crown, should Jogaila predecease his cousin then the Poles should not elect another king without the agreement of Vytautas and/or the Lithuanians. Jogaila sought throughout to move the grand duchy from the Gediminids in general to the Algirdaičiai and eventually the Jogailaičiai in particular. According to the Prussian chronicler Johann

${ }^{24}$ Codex diplomaticus prussicus [CDP], ed. J. Voigt, VI, 87, Königsberg,1861; Osnabrück, 1965, 91: "des graffen von czilen bruder tochter und sie meynen das die selbe die nehste erbling sey czum Riche czu Polan".

${ }^{25}$ Cf. J. Dąbrowski's opinion cited in Dzieło Jadwigi i Jagiethy. W sześćsetlecie chrzestu Litwy i jej zwiqzków z Polską, oprac. W. Bilinski, Warszawa,1989, 67. 
von Posilge, in 1401 not only the Lithuanians and Russians swore renewed allegiance to Jogaila but so did the Poles and Mazovians ${ }^{26}$. The rather verbose cadences of the union of Horodło stress repeatedly the persons and successors of the king and grand duke. At the same time the Grand Duchy was balanced with the kingdom as regards aristocratic privileges, as in the run up to the Union of Lublin Poland would be balanced in land holdings with the previously much larger Grand Duchy. In 1434 Jogaila granted his other cousin, Žygimantas, the grand duchy for life - minus the extra privileges which had been given to Vytautas.

Having concentrated thus far on the dynastic agents of the union, we cannot avoid looking in a little more detail at what form that union took. In short, was the Grand Duchy incorporated into the Polish kingdom and what did this alleged incorporation mean? The problem, which is as thorny as it is unresolvable (since it thrives mainly in the mind of the interpreter), can be examined in at least two aspects: when did the word incorporare first appear in union debates and what was the context of such debates; and secondly, how was the process carried out (if indeed it was carried out)?

Perusing the surviving "acts of union" as published by S. Kutrzeba and W. Semkowicz, it seems that the various acts of union develop gradually more elaborate terminology, as the Jagiellonian roots in the union and especially in the Kingdom become better established. The first agreement stresses the adhesion of Poland to Lithuania (and vice versa), the glue being Jogaila and Jadwiga. The term is deliberately vague. Re-evaluations of the political situation in Lithuania (1392) and the united monarchy as a whole (1401 at Radom and Vilnius) elicited 'negative' promises from the Lithuanian side that Vytautas would not desert his cousin the king or his crown and his realm of Poland and that he would be grand duke for life, returning the grand duchy and his own patrimonial lands to the supreme duke. The 1401 agreement acknowledges Jogaila's position in both the realms. It is with the agreement struck at Horodło in 1413 that the meaning of applicare is made less vague (one hesitates to say "more specific"). This act came at a time that Jogaila and his cousin had been investigated by international lawyers, that the king-supreme duke had an heiress who had survived the most perilous years of infancy (Jadwiga was five years old) and that the political situation inside the Grand Duchy was under review in light of the need to convert and govern the pagan Žemaitians. To be absent from the conversion of the last of Lithuania's pagans would weaken Jogaila's role as baptiser of the heathens and supreme duke of Lithuania. It would weaken his

26 "machte Jagil der koning von Polan uff eyn nuwes mit Wytowte eyne vorbindunge und mit den Russin und den Polan und den herczogen von der Massow, und den bischoffen", in SRP, III, 245. Cf. Grand Master's letter to commander of Vienna: "so wissedt, das uns czu wissen worden ist, das von stadenan noch dem tode der seligen frawen konigynne von Polan, die Polan uffs nuwe Jageln swuren und holdten, do woren kegenwortig czwene der fursten us der Massaw" in CDP, VI, 87, 1861, 90. 
international stance and diminish his prestige as supreme duke. The Horodło acts operate on many levels. The accord stresses the Catholic unity of the dual monarchy and introduces the first official reference to a threat from the Teutonic Order. It confirms Lithuanian aristocratic equality with the Polish szlachta and gains the recognition by both Lithuanians and Poles of a Jagiellonian succession ${ }^{27}$. Should the line of Jogaila fail and the king predecease his cousin, then Vytautas and the Lithuanian nobles will be consulted before the election of a new king. If we attempt the difficult task of analysing the provenance of the Lithuanian nobles who sealed the treaty, then it appears that there were marginally more boyars of Žemaitian extraction at Horodło than there had been at Radom-Vilnius twelve years earlier. That Žemaitija was Lithuanian and the co-inheritance of Jadwiga Jogailaite and Sofia Vytautiene was stressed by the Grand Duchy's lawyers in their dealings with the Order. In his description of the king's visit to Žemaitija, Długosz stresses the role of Jogaila as preacher and the presence of the complete royal family during the expedition: Queen Anne and the co-heiress, Jadwiga. The message is clear: Žemaitija is Lithuanian, Lithuania is the equal of Catholic Poland and both the Kingdom and the Grand Duchy belong to Jogaila and the heirs of his body. It was at Jedlno in 1413 that the Polish nobles recognised Jadwiga's Polish inheritance rights: "wir mustin euwir Tochter horigen und sweren sye czu halden vor eyne Koniginne"28. The birth of a son to Queen Sofia in 1424 resulted in the swift recognition of Władysław as heir to Jogaila's throne ${ }^{29}$. The following year oaths of allegiance being sworn by various burgher communities, promising to serve Jogaila, his son, Władysław, the latter's guardians, Grand Duke Vytautas and Queen Sofia, and the princess Jadwiga, should Władysław die in the mean time ${ }^{30}$. Later in the fifteenth century the union was reviewed periodically in times of particular difficulty, either in the dynasty or in the political life of either the Kingdom or the Grand Duchy. In 1446 the suggestion that the dual monarchy be transformed into a single state of equal provinces under the style "Regnum Polonie" was vigorously rejected by the Lithuanian party ${ }^{31}$.

${ }^{27}$ Much stress is laid on the rights of Catholic nobles (AUPL, 51,1932, 64). This would seem to place the Orthodox boyars of Lithuanian Rus at a dangerous disadvantage. It may be, however, that for diplomatic purposes, the rights of the 'schismatic' nobility are recognised secretly under clause 14 (ibid., 68) - the letters issued around the time of Coronation and eight or nine years before Horodło (cf. Gramoti XIV st., ed. M.M. Peshchak (Kiev, 1974) and Ukrains'ki gramoti XV st., ed. V.M. Rusanivs'kii (Kiev,1965).

${ }^{28}$ Kodeks dyplomatyczny Litwy, oprac. E. Raczyński, Wrocław, 1845, 386.

29 Jogaila to Pope Martin V, November 1, 1424: "et regni terrarumque mearum gubernacula, que spaciosa complectitur ambitur, velud heres et successor feliciter in Domino possidebit", in $C E V, 1169,1882,680$.

${ }^{30}$ Kodeks dyplomatyczny Wielkopolski, VIII, oprac. A. Gąsiorowski,T. Jasiński, Warszawa-Poznań, 1989, Nos. 1021, 1023-1025, 1029, 1031, 1039-1041, 1044-1047.

${ }^{31}$ Dhugosz, XIII, 46-47. 
The question naturally arises as to how far and in what ways the union was carried out. This too has some importance for how we regard the written statements of incorporation which were repeated after 1413 .

As is clear, the dynasty is one element which united and influenced both parts of the monarchy. The best example of the union personified is Queen Sofia, scion of a Lithuanian boyar family serving their affine Vytautas in Rus. This marriage served to draw Vytautas and Jogaila closer together and strengthen dynastic ties. Sofia exploited her family connections in the Grand Duchy and her contacts in Poland as royal consort and later, dowager queen, to strengthen the power of her sons as king and grand duke. However, not all estates embodied the union to the same degree as the ruling dynasty.

After the conversion (1386-7) the ecclesiastical hierarchy in Lithuania was inevitably of foreign origin, but soon was replaced by local candidates. In a certain sense the Lithuanian church was incorporated into the Polish province until Decemeber 1991, but this does not mean that it was completely dominated by Polish hierarchs. Jerzy Radziwił’'s Polish cardinalacy in the sixteenth century, and the dispute over the succession to the see of Vilnius after the death of Bishop Matthew at the height of an anti-Casimirian rebellion in 1453 (he was replaced by a non-Polish candidate, Nicholas) are not the only examples of particularist successes ${ }^{32}$.

Was the union embodied by the secular lords of the realm? Although the Scandinavian and Polish nobilities both sought to elect a controllable monarch, the intermarriage which typified relations between the aristocracies of Denmark and Sweden did not exist in Poland-Lithuania ${ }^{33}$. Certain groups of nobles did reside at court in other parts of the monarchy. Jadwiga kept Lithuanian ladies in her court in Cracow; when ladies-in-waiting testified against Queen Sofia Alšèniškaitè when she was accused of adultery they were sent away into Lithuania and married off ${ }^{34}$. During Vytautas's reign Polish born officials served him in Vilnius, but these usually used this time as a stepping stone to promotion inside the kingdom and their places were taken subsequently by subjects of the Grand Duchy. Similarly in the Iberian union, local Aragonese nobles complained bitterly that key posts were handed out to Castilian interlopers.

Lithuanian nobles certainly came under Polish cultural influence. Poland presented neophyte Lithuania with an entrée into full mem-

32 L. Kołankowski, Dzieje Wielkiego Księstwa Litewskiego za Jagiettonów, I, Warszawa, 1930, 276; E. Kotlubajus, Radvilos. Nesvyžiaus galerijos portretai. Mykolo Starkmano medžio raižiniai tr. T. Bairašauskaitè, Vilnius, 1995, 172-178.

${ }^{33} \mathrm{H}$. Schück, Sweden as an aristocratic republic, Scandinavian Journal of History IX, 1984, 65-72.

${ }^{34}$ Jadwiga's Lithuanian duchesses: Rachunki dwonu króla Władystawa Jagiełly $i$ królowej Jadwigi $z$ lat 1388-1420, oprac. F. Piekosinski, Kraków,1896, "duabus ducissis circa dominam reginam morantibus" (p.171) and "ducissabus Lythwanicis" (p.66,1389) and in 1394 "domina ducissa filiastris ducis Witoldi" (p.285). 
bership of the international Catholic community where links had already been prepared by Lithuanian emigrants ${ }^{35}$. However, this does not mean that Lithuanian nobles were turned into Poles. At Horodło in 1413 Lithuanians adopted Polish coats of arms, but native devices were stilled employed by some aristocrats. The sharing of blazons was merely a culturally equalising act. Lesser boyars still spoke some Lithuanian, even in the eighteenth century. We must be wary of the classification of political nationality by language or other cultural attributes. That is the freedom mechanism of the nineteenth century, rather than a useful factor for historical research. Close relations between the barons of Poland and Lithuania are not, then, a feature of the Union, especially in its first century. Later, Lithuano-Polish marriages were forbidden by Statute, although in border districts marriage alliances were concluded (especially with Mazovians) and great magnates broke through "ethnic" barriers. A particularly stark example of just how little Lithuanian and Polish nobles cooperated is the 1434 Union agreement whereby Žygimantas Kęstutaitis acknowledged that the Grand Duchy would escheat, after his death, to Jogaila and his heirs. The documents were sealed on February 27. Jogaila and his noble Polish witnesses foregathered at Nowe Miasto Korczyn, not far from Radom; Žygimantas and the Lithuanians stayed at Grodno ${ }^{36}$. Nevertheless, nobles of both halves of the Jagiellonian realm do appear together in battles, as at Grunwald in 1410, which safeguarded Jogaila's patrimonies. When Vytautas attacked Novgorod in 1428, he had the support of Polish allies, but these were largely Mazovian (Kazimierz) or from Wielkopolska (Wincenty of Szamotuły). Even at the height of certain Lithuanian discontent with Casimir in 1453-4, Lithuanian and Žemaitian forces responded to the monarch's request for assistance against the Teutonic Order at the beginning of the Thirteen Years' War.

As is well known, the territories of both the Kingdom and the Grand Duchy were home to various national groups which lived according to their own charters: Jews, Karaites, Tatars and these maintained good relations with their co-religionists resident elsewhere, especially in Constantinople and the Tatar steppes. However, relations between members of these communities in Poland and Lithuania were rarer. The Jewish Pinkas maintained a distance between the four Polish and one Lithuanian council ${ }^{37}$. What these disparate groups have in common is the Jogailaičiai. The first Jogailaitis to be canonised was Casimir, son of Casimir Jogailaitis (d. 1484) in 1604. However, during the sixteenth century Jews, Tatars, Karaim and the merchants of di-

${ }^{35}$ S.C. Rowell, Unexpected contacts: Lithuanians at western courts, c.1316-1400, English Historical Review, 2, 1996.

${ }^{36}$ AUPL, 60 (Korczyn), 61 (Grodno), 1932, 94-99, 100-105.

${ }^{37} \mathrm{M}$. Horn, Zydzi i mieszczanie na słuzbie królów polskich i wielkich księżąt litewskich w latach 1386-1506, Biuletyn zydowskiego Instytutu Historycznego w Polsce, 3-4, 1985, 1-19; 1-2, 1986, 3-17.

${ }^{38}$ S. Kričinskis, Lietuvos totoriai, tr. T. Bairašauskaitè, Vilnius,1993, 23. 
verse towns culted Vytautas, the Tatars even referring to him as "Wattad king of Poland" 38 . Lithuanian and Polish society has still to deal with the political consequences of such socio-political compartmentalisation.

The comparative approach to the history of composite monarchies in late-mediaeval and early modern Europe which has been adopted in recent years may be of use in de-demonising the LithuanoPolish Union by providing a context within which the centralised nation states of the nineteenth century will not encourage the condemnation of early modern polities, of which the Commonwealth is a normative example, to the status of anomaly. Some steps have already been taken along this road, although the comparison of the "northern" unions of Kréva and Kalmar popular during the search for an anti-German third alliance during the 1930 s is not particularly fruitful $^{39}$. In Scandinavia a dynastic union was formulated without a strong royal family but in the presence of an intermarried and powerful nobility. In Poland-Lithuania the royal dynasty survived for almost two centuries in the face of powerful but for the most part determinedly separatist aristocracies. A more illuminating comparison might be drawn between the Commonwealth and the Iberian union of Aragon and Castile, both of which are regarded as abnormal, the one for its later "anarchy", the other for its "totalitarianism". Miguel de Cervantes had no problem dividing the world into north (polonophone) and south (Spanish), referring to both Poland and Lithuania. In the nineteenth century Joachim Lelewel attempted to understand why the great powers of the sixteenth and seventeenth centuries should have declined so markedly by his own day. Although his comparison tends to be somewhat stark (the tyranny of Phillip II contrasted with the democracy of Sigismund Augustus), the principle is a sound one ${ }^{40}$.

There are clear obvious differences between the two states, especially in view of Lithuania's change of religion following the union, however, it is the similarity of the problems facing both Charles V's Spanish Empire and the Jagiellonian union which strike anyone reading the two realms' history. The Spanish imperial idea, that the king of both countries under his care should act in each as though he were ruler only of one, echoes familiarly in Vilnius and Cracow ${ }^{41}$.

In the second half of the fifteenth century the Aragonese needed the support of another political body (eventually the kingdom

${ }^{39}$ O. Halecki, Unia Polski z Litwą a unia kalmarska, in Studia historyczne ku czci St. Kutrzeby, I, Kraków, 1938, 217-232; Z.H. Nowak, Krewo i Kalmar: dwie unie póżnego średniowiecza w północnej i wschodniej Europie, in $W$ kręgu stanowych $i$ kulturowych przeobrazen Europy pótnocnej w XIV-XVIII wieku, oprac. Z.H. Nowak, Toruń, 1988, 57-75.

${ }^{40}$ M. Cervantes, Trabajos de Persiles y Sigismunda; J. Lelewel, Historiczna paralela Hiszpanii z Polskq w XVI, XVII, XVIII wieku, in idem., Polska. Dzieje i rzeczy jej, III, Poznań,1855, 473-512.

${ }^{41}$ In general for what follows on Spain, see: J.H. Elliott, Imperial Spain, 1469-1716, London, 1970, 167, 256-257 and passim. 
of Castile) in order to defend its interests. There were alternatives to Castile (for example, Portugal), just as Lithuania was faced with a possible, but in the event, impractical Muscovite alliance. In 1469 Ferdinand of Aragon married Isabella of Castile, whilst preserving the separateness of their monarchies. As Sir John Elliott has noted, both Iberian realms had experienced a different history and their political development was not identical: Castile was almost four times larger than Aragon in area but her inhabitants made up only a sixth of the joint population. Aragon and her Catalan partner had a particularly strong tradition of parliamentary consultation, whilst in Castile Isabella was queen-proprietor. Aragon's foreign trade and political interests linked her with southern France and Italy and the mediterranean world. The kingdom of Castile looked south to Africa and west to the Atlantic. One might call to mind the divergent geographical accents of Lithuanian and Polish political interests and the Baltic grain trade which played the role of Polono-Lithuanian 'America'. The union was effected in a polyethnic, multireligious land where side by side dwelt Arabs, Jews, "Spaniards", Portuguese and migrants from Italy and France. As a result of the Reconquista Spain was the focus of aristocratic and pilgrim attention from all over western and central Europe. In the fifteenth century Polish and Lithuanian pilgrims also came to wend their way to pray at the shrine of St James in Compostella. Fifteenth-century Spanish theologians were faced with the need to consider the rights of non-Christians just as Jogaila's canonist Pawel of Vladimir defended Lithuanian rights before the Council of Constance.

Until the mid-sixteenth century Spain had no fixed royal capital. The location of the royal court in Madrid necessarily strengthened Castilian influence in the joint monarchy, while the creation of a capital in Warsaw was intended to balance the competition of Vilnius and Cracow for the presence of the Baltic king-grand duke. In 1714 Phillip $\mathrm{V}$ Bourbon was pronounced king of Spain, ending the official joint status of his Spanish territories. No such proclamation was made in Poland-Lithuania. In 1716 the Planta Nueva declaration abolished the separate legal systems of Aragon and Catalonia. Although a joint legal system was announced for Poland and Lithuania in 1569, the Third Lithuanian Statute of 1588 effectively nullified this aspect of the Union of Lublin. A comparative study of the Iberian and Baltic composite monarchies might do much to counter the unnecessarily heavy emphasis on north-eastern European "exoticism".

The conclusion may be drawn that the strongest linking factor running through the history of the Lithuano-Polish union, at least in its early decades, is provided by the Jagiellonian dynasty. Such a conclusion is by no means novel, but it is underestimated. It is in the dynasty that we find an equal joint monarchy, neither of whose parts was capable of incorporating or subordinating the other, however much certain interest groups may have wished to do so, however more 
"modern" the political infrastructure of the Polish duchies may have been at first. Much research remains to be done into the social history of the Grand Duchy and her component provinces before the stereotypes of certain nineteenth-century historiography can be laid to rest. The Baltic dual monarchy is often portrayed as the enfant terrible of European history. In reality, like the Habsburg Spains, it was more of a wunderkind, a child prodigy of such a size that the political communities, dynastic or noble were unable to coordinate its gangling limbs. In its essential features it was typical of its time. What may lead historians to classify it as untypical of "Europe" (which Europe do we have in mind?), is that it lasted so long. The Anglo-French dual monarchy, established by the Treaty of Troyes (1420), provoked during its short life similar fears of mutual domination and "incorporation" Union thrived in dynamic of political tension, but failed to provide a strong political centre, either before 1569 or even less so after Lublin. The Constitution of 1791, supported more in Lithuania than the Kingdom, may have led eventually to a northern "Nueva Planta", but the final partitions ensured that it would remain only a paper tiger.

42 "Although Henry [V] and his heirs were to rule both kingdoms, each was to remain separate from the other. France was to retain its own institutions, it was to be ruled by Frenchmen", in A. Tuck, Crown and Nobility, 1272-1461. Political conflict in late medieval England, London, 1985, 258. 